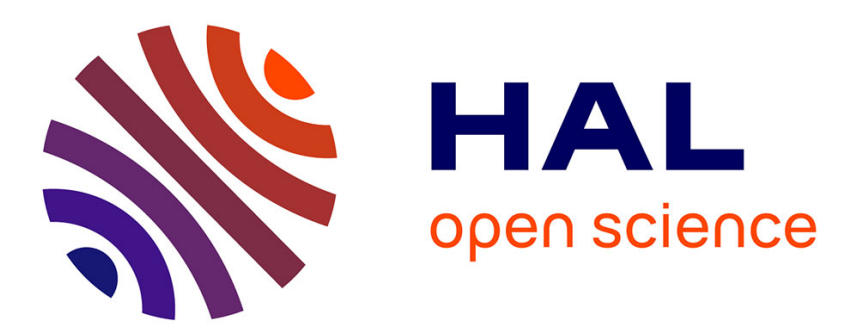

\title{
Using WRF-Chem Volcano to model the in-plume halogen chemistry of Etna's 2018 eruption
}

Luke Surl, Simon Warnach, Thomas Wagner, Tjarda J Roberts, Slimane Bekki

\section{To cite this version:}

Luke Surl, Simon Warnach, Thomas Wagner, Tjarda J Roberts, Slimane Bekki. Using WRF-Chem Volcano to model the in-plume halogen chemistry of Etna's 2018 eruption. 22nd EGU General Assembly, 2020, Online, France. 10.5194/egusphere-egu2020-10892 . insu-03560752

\section{HAL Id: insu-03560752 \\ https://hal-insu.archives-ouvertes.fr/insu-03560752}

Submitted on 8 Feb 2022

HAL is a multi-disciplinary open access archive for the deposit and dissemination of scientific research documents, whether they are published or not. The documents may come from teaching and research institutions in France or abroad, or from public or private research centers.
L'archive ouverte pluridisciplinaire HAL, est destinée au dépôt et à la diffusion de documents scientifiques de niveau recherche, publiés ou non, émanant des établissements d'enseignement et de recherche français ou étrangers, des laboratoires publics ou privés.

\section{(c)(1)}

Distributed under a Creative Commons Attribution| 4.0 International License 
EGU2020-10892

https://doi.org/10.5194/egusphere-egu2020-10892

EGU General Assembly 2020

(c) Author(s) 2022. This work is distributed under

the Creative Commons Attribution 4.0 License.

\title{
Using WRF-Chem Volcano to model the in-plume halogen chemistry of Etna's 2018 eruption
}

\author{
Luke Surl ${ }^{1,2}$, Simon Warnach ${ }^{3,4}$, Thomas Wagner ${ }^{3}$, Tjarda Roberts ${ }^{1,2}$, and Slimane Bekki ${ }^{2}$ \\ ${ }^{1}$ Laboratoire de Physique et Chimie de l'Environnement et de l'Espace (LPC2E), UMR 7328 CNRS and Université d'Orléans, 3 \\ Avenue de la Recherche Scientifique, 45071 Orléans, France \\ ${ }^{2}$ Laboratoire Atmosphères, Milieux, Observations Spatiales, Service d'Aéronomie (LATMOS), CNRS, Institut Pierre Simon \\ Laplace, Pierre et Marie Curie University, Paris, France \\ ${ }^{3}$ Max-Planck-Institut für Chemie (MPIC), Mainz, Germany \\ ${ }^{4}$ Insitut für Umweltphysik, Universität Heidelberg, Germany
}

Volcanic eruptions emit halogen-containing species in varying quantities, with their emission ratio to tracer species such $\mathrm{SO}_{2}$ varying between volcanoes, eruptions, and even phases of an eruptive event.

The bromine explosion is known to occur within volcanic plumes, converting bromine from $\mathrm{HBr}$ the primary form in which it is emitted - to other forms, including the spectroscopically detectable $\mathrm{BrO}$. Measurements of $\mathrm{BrO}$ have been made in the plumes of many volcanoes from both groundbased and satellite-based instruments. There also exist a small number of measurements of OCIO.

We present results from WRF-Chem Volcano (WCV), a modified version of the three-dimensional regional atmospheric chemistry and transport model WRF-Chem and associated utilities. We have simulated the Christmas 2018 eruptive event of Mount Etna using a nested implementation the model at maximum lateral resolution of $1 \mathrm{~km}$, as well as a weaker emission plume representing Etna's more common quiescent degassing state. The plume of this 2018 eruption was observed remotely by the TROPOMI instrument.

WCV is able to model the transport and dispersion of the plume. We compare these model outputs to the satellite observations and use this to estimate the volcanic emission column height.

In terms of chemistry, WCV is able to reproduce the bromine explosion and the major features of the satellite observation - including a cross-plume variation in the $\mathrm{BrO} \mathrm{SO}_{2}$ column ratio. We find that variations in the $\mathrm{BrO} / \mathrm{SO}_{2}$ ratio are primarily caused by variations in the concentration of ozone. Ozone is consumed by bromine chemistry and is replenished by the mixing in of ozone-rich background air. This creates a zone of low ozone in the core of the plume which is consequently low in $\mathrm{BrO}$ and surrounded by a higher-ozone edge with a higher $\mathrm{BrO} / \mathrm{SO} 2$ ratio.

For the temporal evolution of the plume, we find that the bromine-chemistry of a concentrated emission plume can be divided into four phases, also governed by ozone availability. In the last phase ozone limitation is minimal and the proportion of bromine in the form of $\mathrm{BrO}$ (and the 
$\mathrm{BrO} / \mathrm{SO} 2$ ratio) is approximately stable. We find this stable regime also with a simulation of a weaker emission plume. These results could facilitate the use of remote-sensing $\mathrm{BrO}$ measurements as a means of quantifying total bromine emissions from volcanoes.

Oxidized forms of chlorine are modelled to be formed within the plume due to the heterogenous reaction of $\mathrm{HOBr}$ with $\mathrm{HCl}$, forming $\mathrm{BrCl}$ that photolyzes and produces $\mathrm{Cl}$ radicals. We also investigate the extent to which mercury could be oxidized by halogens within the plume. 